\title{
Impact of Active Labour Market Policy Programs on Employment in the EU During the Crisis
}

\author{
Lucija Cerar Godec \\ Ceneje, Slovenia \\ lucija.cerar@gmail.com \\ Jože Benčina \\ University of Ljubljana, Faculty of Administration, Slovenia \\ joze.bencina@fu.uni-lj.si
}

\section{ABSTRACT}

Due to the financial crisis and the increase in the unemployment rate, active labour market policy (ALMP) inevitably returned to the forefront with its "activation strategy". The research challenge of the article is analysing the effectiveness of ALMP in the period 2007-2013. The methodology of the work is panel regression with fixed effects estimation. The model estimates the effect of the two largest programs of the ALMP, Training and Employment Incentives, on Employment Rate, considering six additional control variables with potential effect on the labour market. The results demonstrate a positive impact of the Training program on the Employment Rate even in the time of crisis. In contrast, the Employment Incentives program had, along with Passive Labour Market Policy (PLMP), a somewhat negative impact on Employment Rate. The findings provide an insight into the nature of ALMP's implementation during the financial crisis. While the training programs keep their active nature, the employment incentives become reactive and to a certain degree act as a measure of PLMP.

Keywords: effectiveness, Employment Incentives program, employment rate, financial crisis, Training program, unemployment, EU, labour market

JEL:E240, J480, J080

\section{Introduction}

The problem of unemployment is one of the biggest issues and one of the major challenges the European Union (EU) is facing. Over the past ten years, when the global economic crisis occurred and widened, the employment indicator reached its historical minimum in all EU countries (Bánociová \& Martinková, 2017). It led to sharp increases in unemployment in many countries and a resurgence in the numbers of long-term unemployed (Martin, 2014). 
The range of various programs and measures that EU countries directly and selectively intervene in the labour market in order to reduce unemployment and increase employment can be classified as an active labour market policy (Svetlik \& Batič in Svetlik et al., 2002). Programs that are designed to help unemployed people also help them acquiring the skills they need and that are desirable in the labour market (Nie \& Struby, 2011).

The main goal of the ALMP is to improve the functioning of the labour market for unemployed persons and have them return to work in various ways, therefore a high level of employment would be maintained (Svetlik \& Batič in Svetlik et al., 2002). ALMP usually includes training and education programs, employment programs, job creation and others. As a result, it is not only a means of social protection but also a tool for economic policies and businesses that need to be adapted (Sahnoun \& Abdennadher, 2018). Due to the financial crisis, ALMP inevitably returned to the forefront with its "activation strategy" in order to help reduce unemployment, especially long-term unemployment, and help find other risk groups jobs (Martin, 2014). Card, Kluve and Weber (2017) found with regard to the state of the labour market that ALMPs tend to have larger impacts in periods of slow growth and higher unemployment.

Active labour market policy is intertwined with various macroeconomic indicators, such as unemployment, inflation and GDP, and therefore assessment and measurement are very complex. Due to the wide use of ALMP in and outside of the EU Member States, the need for measurement and the importance of assessing the achieved performance of its operation is increased. However, there is little recent research (from 2008 on) that has evaluated the major active labour market policy programs.

The aim of our research is to assess the effect of the two biggest ALMP programs, namely Training and Employment Incentives, on the Employment Rate. The time line covers the financial framework of the European Social Fund for the period 2007-2013 in the EU Member States. The methodology used is panel regression, which is estimated by the method of fixed effects.

The second chapter deals with a general overview of previous empirical research. The third chapter presents the methodology of the work and the description of the variables. The research results are presented in the fourth chapter. The last chapter follows up the conclusion with a discussion on the results of the research in light of the results of previous studies.

\section{Research on Effects of ALMP Programs}

ALMP programs are complex and operate within a variety of contextual conditions, therefore their evaluation is difficult. Often, the target groups encounter large barriers to (re)integration into the labour market. Techniques to improve the employability and employment opportunities of the ALMP participants are difficult to standardise. Labour market interventions cannot 
function separately, but only in combination with other policies and programs under different structural and economic conditions. Being so, the results are difficult to measure in the short term (Bredgaard, 2015). Assessments based on microdata show that the effects of the ALMP on employability do not appear or they are small in the short term. The long-term effects in terms of employability are generally more visible or expressed (Boone \& Van Ours, 2004). This encourages research in the long run, including monitoring the employability of workers and thus monitoring the performance of individual ALMP policies (European Union, 2016).

Besides, there are few recent macroeconomics studies that analysed the effects of ALMP programs, except the research of Escudero (2018). In his research, Bredgaard (2015) even argues that a database that would support research on how ALMP programs actually work is not yet available. Despite the data accessibility hindrance, a number of researchers studied the impact of ALMP on employment or unemployment rate in the time periods from 1985 until 2008 (Kluve \& Weber, 2009; Kluve, 2010; Heckman et al., 1999; Kluve and Schmidt, 2002; Kluve et al., 2002; Card et al., 2010, Nie and Struby, 2011; Laporšek and Dolenc, 2011; Boone and van Ours, 2004; Estevão, 2003; Estevão, 2007). For the last two decades, EUROSTAT and OECD (Eurostat, 2016; OECD, 2016c) have collected and published comparable data about both Active and Passive Labour Market Politics. Surprisingly, there are no macroeconomic studies analysing the period from 2007 to 2013 (seven year long financial framework of the European Union), even though the data are available and insight into the impact of the ALMP in that period is very much needed.

In the rest of the chapter, we present the research framework, methodological approach and major results of the studies that we have drawn from in the definition of our research design. The overview of the main characteristics of the research presented is given in the Table at the end of the chapter.

In their research, Laporšek and Dolenc (2005) studied the relationship between the programs of Active and Passive Labour Market Policy, labour relations legislation and lifelong learning programs relating to the Employment Rate, the rate of unemployment and the long-term unemployment rate. The methodology used in their research was panel regression, and the models they used were evaluated with the fixed and random effects model. The analysis was carried out for twenty EU Member States in the period 1990-2008. The analysis showed that expenditure on an active labour market policy was positively related to the labour market, thus affecting a reduction in the unemployment rate and an increase in the Employment Rate. On the other hand, expenditures dedicated to Passive Labour Market Policy (PLMP) negatively correlated with the transition from unemployment to employment. Their research brought attention to the importance of creating a balanced employment policy for the further development of the European labour market and the economy (Laporšek \& Dolenc, 2011). 
Boone and van Ours (2004) examined the effectiveness of ALMP at the aggregate level. They analysed (with analysis of time series) the effects of the ALMP (Training and Employment Incentives) programs on the employment-population rate and the unemployment rate in twenty OECD countries for the period 1985-1999. They found that the expenditures for the Training program provide a significant positive impact on the labour market. Furthermore, they observed that the expenditures of public employment services had a certain impact on unemployment but had no effect on the Employment Rate of the entire population, whereas the Employment Incentives programs were not successful at all.

In his research, Estevão (2003) analysed panel data for 15 industrial countries, employing the ordinary least square model. He found that in the 1990s the most successful program was the subsidy for direct job creation. However, that was not the case in the 1980s, when the expenditure for the ALMP was relatively smaller. Training programs had largely proved to be unsuccessful in terms of intended expenditures. In a subsequent study, the same author (Estevão, 2007) analysed data under the same research strategy for the same set of countries in the period from 1985-2000, observing several different periods of years and different set of independent variables used (see Table 1). He concluded that the ALMP as a whole had a statistically significant positive impact on the Employment Rate. The most successful programs were subsidised employments programs, while the Training programs did not show statistically significant influence. Moreover, the Labour market services showed a statistically significant negative impact on the Employment Rate over the whole period.

Nie and Struby (2011) formulated three fixed effects models for the unemployment rate. They used data for 20 OECD countries for the period from 1998 to 2008. They found the common ALMP to be cost-effective in reducing unemployment. Programs were beneficial in the main categories of the ALMP, in the Training program and in labour market services (Job-Search Assistance). Both programs also had an influence on reduction of the unemployment rate. Measures covered by the smallest category of the ALMP (other policies) (see Table 1) also reduced unemployment. Conversely, Direct Job Creation had a negative effect on the unemployment rate and the Supported Employment program did not show a statistically significant difference.

Escudero (2018) examined the effectiveness of ALMPs in improving labour market outcomes, especially of low-skilled individuals, by means of a pooled cross-country and time series database for 31 advanced countries during the period 1985-2010. The analysis included aspects of the delivery system to see how the performance of ALMPs is affected by different implementation characteristics. Among the notable results, the paper finds that ALMPs matter at the aggregate level, but mostly through appropriate management and implementation. In this regard, sufficient allocation of resources to programme administration and policy continuity appeared to be particularly important. Moreover, start-up incentives and measures aimed at vulnerable populations are 
more effective than other ALMPs in terms of reducing unemployment and increasing employment. Interestingly, the positive effects of these policies seem to be particularly beneficial for the low skilled. Training, in contrast, seems to be effective for the overall population; however, it also has positive effects for the low skilled through the interaction with implementation variables.

Table 1 on the next page summarises previous research, with the complete data and the impact of independent variables.

Table 1: Overview of the research on the effectiveness of the ALMP

\begin{tabular}{|c|c|c|c|c|c|c|}
\hline Author & Units & $\begin{array}{l}\text { Time } \\
\text { period }\end{array}$ & Method & Independent variables & Impact & $\begin{array}{l}\text { Depend. } \\
\text { variable }\end{array}$ \\
\hline \multirow{16}{*}{ 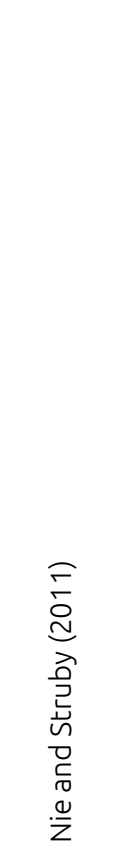 } & \multirow{16}{*}{ 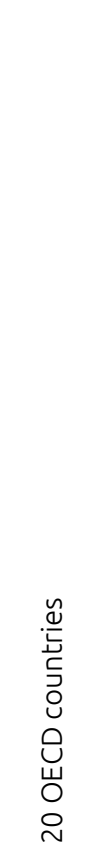 } & \multirow{16}{*}{$\begin{array}{l}\infty \\
\stackrel{0}{0} \\
\stackrel{\sim}{1} \\
\stackrel{2}{ } \\
\text { }\end{array}$} & \multirow{16}{*}{ 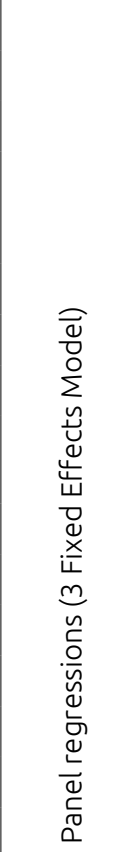 } & Labour force participation rate & - & \multirow{16}{*}{ 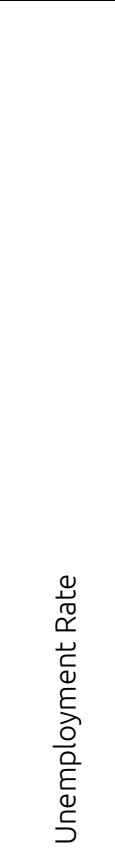 } \\
\hline & & & & Union Density & - & \\
\hline & & & & Employment Protection & 0 & \\
\hline & & & & \multirow{2}{*}{ Tax Wedge } & - (model_1,3) & \\
\hline & & & & & 0 (model_2) & \\
\hline & & & & Output Gap & + & \\
\hline & & & & ALMP & + & \\
\hline & & & & PLMP & 0 & \\
\hline & & & & $\begin{array}{l}\text { Initial Unemployment Benefit } \\
\text { Replacement Ratio }\end{array}$ & 0 & \\
\hline & & & & Unemployment Benefit Duration & - & \\
\hline & & & & Job-Search Assistance & + & \\
\hline & & & & Training & + & \\
\hline & & & & Employment Incentives & 0 & \\
\hline & & & & Supported Employment & 0 & \\
\hline & & & & Direct Job creation & - & \\
\hline & & & & Other policies & + & \\
\hline & & & & Employment Protection & $-E R$ & \\
\hline $\mathcal{E}$ & & & 选 У & Participation in LLPs & 0 & d́ \\
\hline$\stackrel{\ominus}{\varrho}$ & & & $\stackrel{0}{\mathscr{L}}$ & ALMP & + & \\
\hline 宅 & 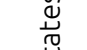 & & 遈崖 & PLMP & $+E R$ & . \\
\hline$\overline{0}$ & $\stackrel{\omega}{\tilde{\alpha}}$ & & 은 & Tax Wedge & - & 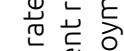 \\
\hline 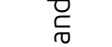 & है & & $\stackrel{\widetilde{d}}{0} 0$ & Union Density & + ER - LTER & 岇 \\
\hline 离 & $\sum_{\longrightarrow}^{\infty}$ & 定 & 品寅 & GDP per capita & $\begin{array}{l}\text { + ER } \\
\text { - UR, LTUR }\end{array}$ & 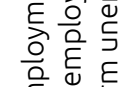 \\
\hline 号 & $\stackrel{\circ}{\sim}$ & $\stackrel{\text { ळे }}{\rightleftharpoons}$ & $\Sigma^{0} \sum^{0}$ & GDP growth & $-E R$ & Е્ \\
\hline
\end{tabular}




\begin{tabular}{|c|c|c|c|c|c|c|}
\hline Author & Units & $\begin{array}{l}\text { Time } \\
\text { period }\end{array}$ & Method & Independent variables & Impact & $\begin{array}{l}\text { Depend. } \\
\text { variable }\end{array}$ \\
\hline \multirow{7}{*}{  } & \multirow{7}{*}{ 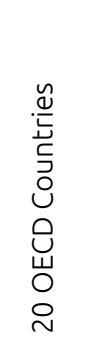 } & \multirow{7}{*}{ 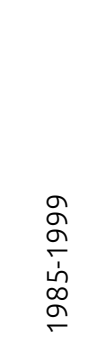 } & \multirow{7}{*}{  } & Union Density & - & \multirow{7}{*}{  } \\
\hline & & & & Unemployment benefits & - & \\
\hline & & & & Tax rate & 0 & \\
\hline & & & & Inflation & $-E R$ & \\
\hline & & & & Job-Search Assistance & $+U R$ & \\
\hline & & & & Training Рrograms & $+E R+U R$ & \\
\hline & & & & Employment Incentives & 0 & \\
\hline \multirow{11}{*}{ 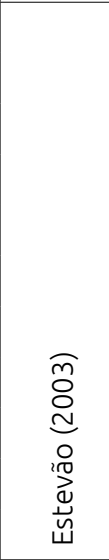 } & \multirow{11}{*}{ 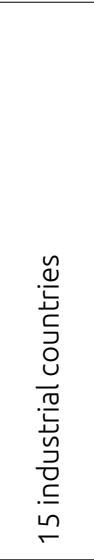 } & \multirow{11}{*}{ 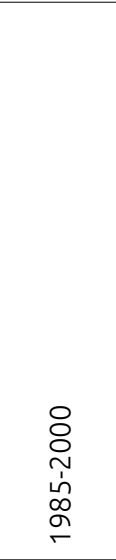 } & \multirow{11}{*}{ 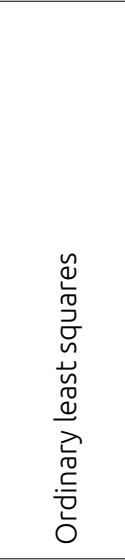 } & ALMP & + & \multirow{11}{*}{  } \\
\hline & & & & PLMP & - & \\
\hline & & & & Technological growth & - & \\
\hline & & & & Log GDP Business (per capita) & - & \\
\hline & & & & Openness & - & \\
\hline & & & & Replacement Rate & - & \\
\hline & & & & Union Density & - & \\
\hline & & & & Share Public Empl. & - & \\
\hline & & & & Employment protection & - & \\
\hline & & & & Bargaining coordination & - & \\
\hline & & & & Central Bank Independence & - & \\
\hline \multirow{7}{*}{ 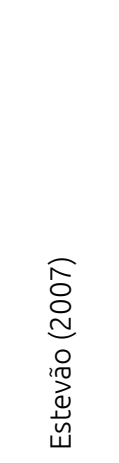 } & \multirow{7}{*}{  } & \multirow{7}{*}{ 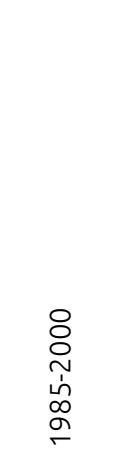 } & \multirow{7}{*}{ 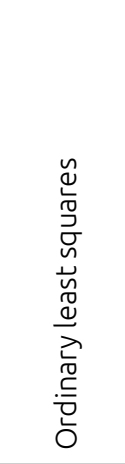 } & ALMP expenditures/GDP & + & \multirow{7}{*}{  } \\
\hline & & & & PLMP expenditures/GDP & + & \\
\hline & & & & Replacement rate & - & \\
\hline & & & & Union membership & - & \\
\hline & & & & Employment protection & $\begin{array}{l}+(1993- \\
2000) \\
-(1985- \\
2000)\end{array}$ & \\
\hline & & & & Bargaining coordination & + & \\
\hline & & & & Tax wedge & - & \\
\hline
\end{tabular}


Impact of Active Labour Market Policy Programs on Employment in the EU During the Crisis

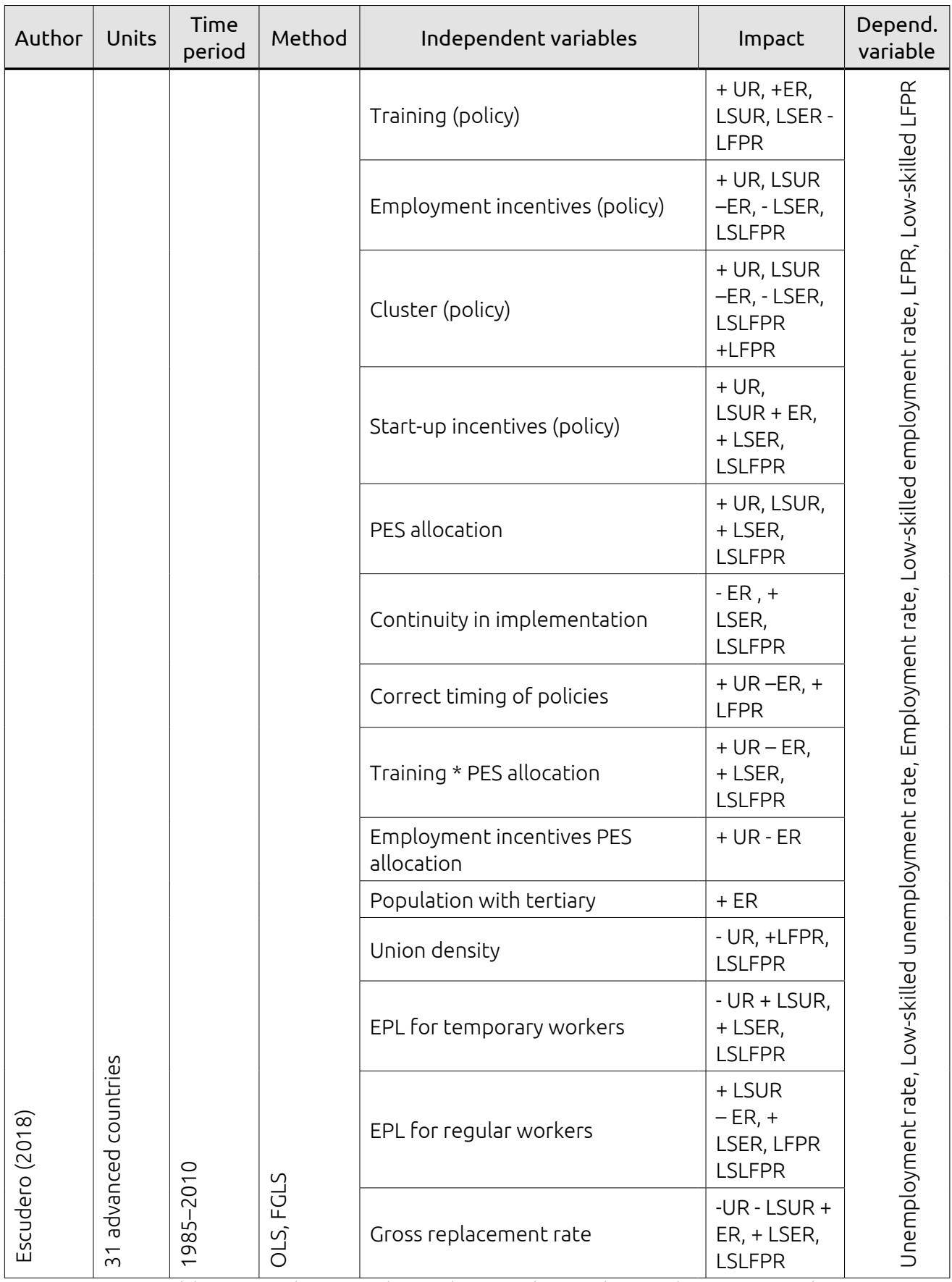

Source: Would Active Labour Market Policies Help Combat High U.S. Unemployment? (Nie and Struby, 2011), Do Flexicurity Policies Affect Labour Market Outcomes? An Analysis of EU Countries (Laporšek and Dolenc, 2011), Effective Active Labour Market Policies (Boone and van Ours, 2004), Do Active Labour Market Policies Increase Employment? (Estevão, 2003), Labour Policies to Raise Employment (Estevão, 2007), Are active labour market policies effective in activating and integrating low-skilled individuals? An international comparison (Escudero, 2018) 


\section{Methods}

The research presented covers the financial framework of the European Social Fund for the period 2007-2013 in the EU Member States. The aim of the research is to assess the effect of the two largest ALMP programs, namely Training and the Employment Incentives Program, on the Employment Rate. The methodology used is panel regression with fixed effects estimation, as used in above mentioned previous research (Nie and Struby, 2011). The variables used in the research are recapped in Estevão (2003), Estevão (2007) and Boone and van Ours (2004).

In the following paragraphs, the general characteristics of panel regression modelling and the specific model tailored for the needs of this study, along with the description of variables, are presented.

\subsection{Panel Regression}

Panel data has two dimensions, namely a cross-sectional and a time dimension. When the cross-sectional units have the same number of observations, this is called a balanced panel data set. In the case of a different numbers of observations, the data set is unbalanced. Panel data provide more informative data, greater variability, more degrees of freedom, less correlation between variables and greater efficiency (Verbeek, 2004).

Panel data analysis can be understood as a combination of regression and time series analysis. It is based on repetitive patterns of variance, since the findings of the units are repeated through the time dimension. By examining the repeated intersection of data observation, the panel detects and measures effects that cannot be detected in a clean section or in a time series of data. Since the panel data is taken into account by the dynamics of the cross-sectional data recurring over time, the effect of the unmodified variables can be controlled. When the cross-sectional observations over a long period of time are examined, the analysis of panel data provides a better explanation of the phenomenon, less collinearity and more efficiency than a cross-sectional or longitudinal analysis. Panel regression therefore provides us with greater patterns and greater flexibility in data processing and offers the possibility of studying heterogeneous phenomena (Verbeek, 2004).

The problem of validity and reliability is an important issue in panel analysis. Since the panel data includes both a cross-sectional view and a time dimension, we are faced with a heteroscedasticity problem with cross-sectional data (which can be a consequence of unsuitable merging of groups) as well as autocorrelation for time series data, where coefficients of variance of coefficients and variance of random errors become biased. There are also some additional problems, such as cross-correlations in individual units at the same time. All of these problems need to be addressed in the analysis (Gujarati, 2004). 
For panel regression evaluation in professional literature, two approaches are most frequently used, i.e. the Fixed Effects Model (FEM) and the Random Effects Model (REM). Being assumed that $u_{i}$ (errors) and $X_{i}$ (independent variables) are related, it is more appropriate to use the FEM model. An example of such a situation is a random sample of a large number of individuals whose salary, earnings of function are modelled. It is assumed that earnings are associated with education, work experience, etc. $\varepsilon_{i}$ presents unexplored effects, such as innate abilities and family background. When modelling earnings, it is therefore likely that errors $\varepsilon_{\mathrm{i}}$ will be associated with education (Gujarati, 2004, p. 650).

The term "fixed effects" thus expresses non-coincidental quantities. The Fixed Effects Model is appropriate, especially when a random error related to individual observation can correlate with one or more independent variables. Assuming that the regression coefficient $\beta_{1}$ is constant and $\beta_{2}$ can be distinguished between cross-sections, the Fixed Effects Model with two independent variables can be presented in the form of the following formula:

$Y_{i t}=\beta_{1 i}+\beta_{2} X_{2 i t}+\beta_{3} X_{3 i t}+u_{i t}$

In the formula (1), $Y_{i t}$ is the dependent variable of the state $i$ at time $t, X_{i t}$ is the vector of the independent variables that change over time and across countries. $\beta$ are unknown coefficients that measure the impact of the explanatory variables on the dependent variable, and u presents a random error. The index $i$ means the number of repetitions (e.g. countries) and $t$ denotes the number of time units (years) (Gujarati, 2004, p. 642).

The Random Effects Model is a hierarchical linear model. It assumes that data in analysis are collected from the hierarchy of different populations whose differences relate to this hierarchy. Therefore, the average of the individual effects is completely independent of the explanatory variables. This is expressed in equation (2) below:

$\beta_{1 i}=\beta_{1}+\varepsilon_{i} \quad i=1,2, \ldots, N$

The term $\varepsilon_{i}$ means a random error with a mean value of zero and a variance $\sigma_{\varepsilon}{ }^{2}$. If, for example, four countries are included in the sample, it is common for them that each reflects the mean value $\beta_{1}$ and individual differences for each country in the expression of error $\varepsilon_{i}$.

With the integration of formula (2) into formula (1), we get the formula below:

$Y_{i t}=\beta_{1}+\beta_{2} X_{2 i t}+\beta_{3} X_{3 i t}+\varepsilon_{i}+u_{i t}$

$=\beta_{1}+\beta_{2} X_{2 i t}+\beta_{3} X_{3 i t}+w_{i t}$

The error term consists of two components $\varepsilon_{i}$, which can be either a cross-sectional or individual specific component of error, and $u_{i t^{\prime}}$ which is a combination of the time series and cross-section component of error. The fact that the 
composite error term $\boldsymbol{m}_{i t}$ consists of two (or more) error components derives the name of the term components model expresses (Gujarati, 2004, p. 647648).

In case $T$ (the number of time series data) is large and $N$ (the number of cross-sectional units) is small, it is likely that there will be little difference in the values of the parameters that are estimated by the Random Effects Model and the Fixed Effects Model. In the opposite case, i.e. $N$ is large and $T$ is small, the estimates obtained by different models can vary significantly. In the Random Effects Model, $\beta_{1 i}=\beta_{1}+\varepsilon_{i}$ and $\varepsilon_{i}$ is a cross sectional random component, whereas in the Fixed Effects Model, $\beta_{1 i}$ is considered to be a fixed component. In the latter case, statistical reasoning is conditional on the observed cross-sectional units in the sample. When the cross-sectional units in the sample are considered to be random variations, then statistical inference is unconditional and the Random Effects Model is more appropriate. When it is believed that there are persistent and over time irregular differences between $i$, the more appropriate choice for evaluation is the Fixed Effects Model (Gujurati, 2004, p. 650).

In case $\varepsilon_{i}$ and $X_{i}$ are uncorrelated, the Random Effects Model is more appropriate. The assumption in the Random Effects Model is that $\varepsilon_{i}$ presents a coincidence from the entire population. However, sometimes this is not true. For example - if we want to investigate the level of crime in fifty USA states, it is obvious that in this case the assumption that these fifty countries are a random sample is definitely not true (Gujurati, 2004, p. 650).

\subsection{Measuring Model}

As previously mentioned, the analysis of the effectiveness of ALMP programs has been carried out using a panel regression model. It is intended for aggregate measuring of effects of the two largest ALMP programs, namely the Training program and the Employment Incentives Program, on the Employment Rate.

As stated in the second paragraph of the next chapter, according to the result of the Hausman test, it is assumed that $\varepsilon_{i}$ ( $\varepsilon$ the expression for the error and i presents the number of repetition) and $X$ (independent variables) are correlated. Therefore, the Fixed Effects Model is more suitable than the Random Effects Model (Gujurati, 2004, p. 642). The model can be written in the following formula:

$Y_{i t}(E R)=\beta_{i}+\beta_{1} X_{1 i t}+\beta_{2} X_{2 i t}+\beta_{3} X_{3 i t}+\beta_{4} X_{4 i t}+\beta_{5} X_{5 i t}+\beta_{6} X_{6 i t}+\beta_{7} X_{7 i t}+\beta_{8} X_{8 i t}+\varepsilon_{i t}$

where $Y$ (dependent variable) is the Employment Rate, $\beta_{i}$ is constant in the number of countries' repetitions, and $\beta_{1,2,3,4,5,6,7,8}$ can vary between cross-sections. $X_{1}$ represents the Labour Force Participation Rate, $X_{2}$ Union Density, $X_{3}$ Employment Protection, $X_{4}$ Tax Wedge, $X_{5}$ Output Gap, $X_{6}$ Training, $X_{7}$ Employment Incentives and $X_{8}$ Passive Labour Market Policy. $\varepsilon_{1}$ represents term for 
error. The index $i$ denotes the number of repetitions (countries) and $t$ denotes the number of time units (years).

The model is summarised in Nie and Struby (2011) and is adapted to the aim of our research. The difference between model specifications in both studies is that in our research the dependent variable is the level of work activity, while Nie and Struby have used unemployment rate. As could be seen from the Table 1 , a number of researchers used a very similar approach to us, with only slightly different definitions of the work activity (Laporšek and Dolenc, 2011, Estevão, 2007, Boone and van Ours, 2004, Estevão, 2003).

At the independent variables side, our model also includes variables from the previous research (Table 1). It considers a selection from the whole list of variables chosen according to the needs of our study. The data was obtained from the OECD and Eurostat websites (Eurostat, 2016; OECD, 2016). The variables forming our measuring model are presented $n$ the next page in Table 2. 
Table 2: Description of variables

\begin{tabular}{|c|c|c|}
\hline Model & Variable & Description of variables \\
\hline Y & $\begin{array}{l}\text { Employment } \\
\text { Rate }\end{array}$ & $\begin{array}{l}\text { Employment Rate is the percentage of the working } \\
\text { population in the working age population. }\end{array}$ \\
\hline \multirow{8}{*}{$x$} & $\begin{array}{l}\text { Labour } \\
\text { Force } \\
\text { Participation } \\
\text { Rate }\end{array}$ & $\begin{array}{l}\text { Labour Force Participation Rate is the percentage of the } \\
\text { active population in the working age population. The } \\
\text { working population consists of active employed persons } \\
\text { and unemployed persons. The working age population } \\
\text { refers to people aged } 15 \text { to } 64 \text {. }\end{array}$ \\
\hline & $\begin{array}{l}\text { Union } \\
\text { Density }\end{array}$ & $\begin{array}{l}\text { Union Density is the relationship between workers that are } \\
\text { members of union density and those who are not. }\end{array}$ \\
\hline & $\begin{array}{l}\text { Employment } \\
\text { Protection }\end{array}$ & $\begin{array}{l}\text { Employment Protection is the measure of the strictness } \\
\text { of the rules on individual and collective redundancies in } \\
\text { employment contracts. It is expressed as a percentage, } \\
\text { namely as the ratio between individual and collective } \\
\text { redundancies. }\end{array}$ \\
\hline & Tax Wedge & $\begin{array}{l}\text { Tax Wedge is defined as the ratio between paid employee } \\
\text { taxes (at } 100 \% \text { average earnings) and the associated } \\
\text { costs for the employer. The average tax wedge measures } \\
\text { the range from which tax on work income leads to } \\
\text { discouraging employment. }\end{array}$ \\
\hline & Output Gap & $\begin{array}{l}\text { Output Gap is the difference between actual GDP and } \\
\text { potential GDP and is expressed as a percentage of } \\
\text { potential GDP. It is calculated as shown in the formula: } \\
\frac{\text { (Actual GDP - potential GDP) }}{\text { potential GDP }} \text { Potential GDP is higher than actual GDP. }\end{array}$ \\
\hline & $\begin{array}{l}\text { Training } \\
\text { program }\end{array}$ & $\begin{array}{l}\text { Expenditures are intended for the Training program, } \\
\text { which falls within the active labour market policy. Those } \\
\text { expenditures are public for various programs and } \\
\text { measures, such as institutional training, workplace training, } \\
\text { interactive training and special support for internships. }\end{array}$ \\
\hline & $\begin{array}{l}\text { Employment } \\
\text { Incentives } \\
\text { program }\end{array}$ & $\begin{array}{l}\text { Expenditures are intended for the Employment Incentives } \\
\text { program, which falls within the active labour market policy. } \\
\text { Those expenditures are public for various programs and } \\
\text { measures, such as employment promotion (permanent } \\
\text { and temporary employment), incentives that help maintain } \\
\text { employment, rotations and work division. }\end{array}$ \\
\hline & $\begin{array}{l}\text { Passive } \\
\text { Labour } \\
\text { Market } \\
\text { Policy }\end{array}$ & $\begin{array}{l}\text { Passive Labour Market Policy expenditures are public } \\
\text { and are intended for Out-of-work income maintenance } \\
\text { and support in case of job loss as well as for the Early } \\
\text { retirement program. Expenditures are expressed as a } \\
\text { percentage of GDP. }\end{array}$ \\
\hline
\end{tabular}

Source: Politika trga dela (Jacović, 2010), Labour market policy statistics; Methodology 2013 (European Union, 2013), Aktivno in neaktivno prebivalstvo, Slovenija (Svetin \& Osvald, 2016, pp. 2- 3), Employment rate (OECD, 2016), Labour force participation rate (indicator) (OECD, 2016a). Economic Outlook No 100 November 2016: Output gaps: deviations of actual GDP from potential GDP as \% of potential GDP (OECD, 2016b), Public spending on labour markets (OECD, 2016c), Strictness of employment protection - individual and collective dismissals (regular contracts) (OECD, 2016d), Tax wedge (2016e), Trade Union Density (2016f). 
The previous studies cover different sets of countries over different time periods (Table 1). Our set of countries is in accordance with Laporšek and Dolenc (2011), who used data for twenty EU Member States. As mentioned before, our study comprises the until now uncovered time period from 2007 to 2013 and presents the financial framework of the European Social Fund, while at the same time the time of the financial crisis is also taken into account.

In conclusion, we present the final formula of the measurement model (5), which includes an independent and eight dependent variables:

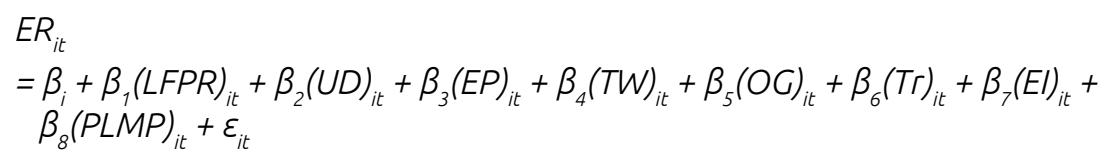

where ER (Employment Rate) is the dependent variable and LFPR (Labour Force Participation Rate), UD (Union Density), EP (Employment Protection), TW (Tax Wedge) OG (Output Gap), Tr (Training), El (Employment Incentives) and PLMP (Passive Labour Market Policy) are independent variables. The impact of independent variables on the Employment Rate is estimated with the fixed effects panel regression model in the country $i$ and year $t$.

\section{Results}

As presented at the beginning of the article, the aim of the research was to analyse the aggregate effect of ALMP programs Employment Incentives and Training on the Employment Rate. To describe the broader situation on the labour market, we included six additional independent variables that had effect on the labour market: Employment Protection, Union Density, Labour Force Participation Rate, PLMP, Tax Wedge and Output Gap. The panel model comprises data in the time span of seven years (2007-2013) for 20 EU countries with 131 observations.

The software program package used to analyse the data was Stata/SE 14.0 for Windows.

Aggregated effects of two ALMP programs and PLMP on the Employment Rate were examined using the panel regression fixed effects model. As the model showed that independent variables and their residuals are not correlated, we also tested the random effects model. It expressed even stronger effects than the fixed model, but the Hausman test $(P=0.056)$ caused us to reject the null hypothesis that the appropriate model was random effect. At that point and in all further hypotheses testing, we use a-level 0.05. We tested the data model for heteroscedasticity and autocorrelation using a modified Wald test for group wise heteroscedasticity in fixed effect regression model and a Wooldrige test for autocorrelation. Both null hypotheses that there is no heteroscedasticity and autocorrelation in our model were rejected. According to Hoechle's (2007) suggestion, we used a fixed effect estimation with Driscoll-Kraay standard errors. 
As can be seen in Table 3, a significant portion of the variance in the dependent variable Employment Rate is explained by the independent variables $\left(R^{2}\right.$ $=0.837)$. The goodness-of-fit is confirmed by a statistically significant $F$ test $(P=0.000)$.

Table 3: Panel regression model characteristics

\begin{tabular}{|c|c|c|c|c|c|c|}
\hline \multicolumn{3}{|c|}{ Fixed-effects regression } & \multirow{2}{*}{\multicolumn{2}{|c|}{$\begin{array}{c}\text { Number of jobs } \\
\text { Number of groups }\end{array}$}} & $=$ & 131 \\
\hline \multicolumn{2}{|c|}{ Group variable: } & \multirow[t]{2}{*}{ ID } & & & $=$ & 20 \\
\hline R-sq: & & & \multicolumn{2}{|c|}{$F(8,6)$} & $=$ & 73,44 \\
\hline \multirow{2}{*}{$\begin{array}{c}\text { within } \\
\text { ER }\end{array}$} & \multirow{2}{*}{$\begin{array}{c}\quad= \\
\text { Coef. }\end{array}$} & \multirow{2}{*}{$\begin{array}{c}0.8375 \\
\text { Drisc/Kraay } \\
\text { Std. Err. }\end{array}$} & \multicolumn{2}{|c|}{ Prob $>$ F } & $=$ & 0.0000 \\
\hline & & & $t$ & $P>t$ & \multicolumn{2}{|c|}{ [95\% Conf. Interval] } \\
\hline UD & 0.0199 & 0.0864 & 0.23 & 0.826 & -0.1916 & 0.23136 \\
\hline LFPR & 0.8284 & 0.0730 & 11.35 & 0.000 & 0.6499 & 1.00695 \\
\hline EP & 3.9463 & 1.1780 & 3.35 & 0.015 & 1.0639 & 6.82877 \\
\hline TW & -0.1510 & 0.0388 & -3.89 & 0.008 & -0.2459 & -0.05613 \\
\hline OG & 0.1555 & 0.0818 & 1.90 & 0.106 & -0.0448 & 0.35575 \\
\hline $\mathrm{Tr}$ & 3.8032 & 0.7653 & 4.97 & 0.003 & 1.9304 & 5.67589 \\
\hline El & -4.5209 & 2.3060 & -1.96 & 0.098 & -10.1634 & 1.12157 \\
\hline PLMP & -3.7288 & 0.5954 & -6.26 & 0.001 & -5.1858 & -2.27180 \\
\hline _cons & 5.5060 & 5.8171 & 0.95 & 0.380 & -8.7280 & 19.73988 \\
\hline
\end{tabular}

Source: Authors' calculations (Statistically significant difference: $P|t|<0.05$ )

The results indicate a statistically significant effect on Employment Rate for five variables. Three variables demonstrate a positive effect: Labour Force Participation Rate $(t=11.35, P=0.000)$, Employment Protection $(t=3.35$, $P=0.015)$ and Training $(t=4.97, P=0.003)$. While the two latter variables manifest the expected positive influence on Employment Rate, Labour Force Participation Rate expresses a somewhat unexpected effect. It would be presumed that Labour Force Participation Rate does not change much either over countries or over time. In the absence of regulation changes or significant migration flows of labour force, it would slightly decrease because of demographic or out-migration changes. On the other hand, a reverse trend could be introduced by changes to labour legislation (retirement age, years of service) or by in-migration flow. As the situation in different countries is more or less different, we would expect only a moderate or no effect of Labour Force Participation Rate on Employment Rate. Nevertheless, as the phenomenon is out of the scope of our study, we leave the question to be answered in future studies.

A negative effect is demonstrated by two variables: Tax Wedge $(t=-1.99$, $P=0.049)$ and PLMP $(t=-7.46, P=0.000)$. Along with the expected role of 
Tax Wedge and PLMP, in light of the research question, we could determine that the variable Employment Incentives $(t=-1.96, P=0.098)$ has a negative effect on Employment Rate at $a=0.1$. At first glance, the negative impact is somewhat surprising. However, in a time of financial crisis, labour market changes induce changes in labour programs, whereas a significant part of this reaction is simply generated by a higher number of unemployed people. Even though the Employment Incentives program is an active labour market policy program, in a time of financial crisis, it becomes more passive or rather has a reactive role.

Still, as presented above, the variable Training manifests the positive influence of investment in training on the Employment Rate. Consequently, we could conclude that unlike Employment Incentives, which takes up a reactive position in a time of financial crisis, Training programs keep their proactive nature even in a time of crisis.

\section{Discussion}

The panel regression analysis was carried out on a sample of twenty EU Member states over the period of seven years (2007-2013). Twenty countries were included in the analysis, namely Czech Republic, Denmark, Poland, United Kingdom, the Netherlands, Estonia, Germany, Greece, Portugal, Austria, Belgium, Italy, Ireland, Slovakia, Spain, Sweden, Slovenia, Hungary, Finland and France. The aim of the analysis was to determine the impact of the two largest ALMP programs, Training and Employment Incentives, on Employment Rate. The analysis was carried out using the Fixed Effects Model. The dependent variable in the model was Employment Rate. Eight independent variables were included (see Table 3).

The results showed that the consumption intended for the Training program had a positive impact on Employment Rate. Therefore, the investment in the program would be remunerated, as the Employment Rate could increase. This finding is similar to the studies by Boone and van Ours (2004) and Escudero (2018) (Table 1).

On the other hand, the Employment Incentives program has a negative impact on the Employment Rate, significant at the a-level 0.01. Even at the a-level 0.1, the negative impact of the Employment Incentives Program on Employment Rate is somehow unexpected, as it tied Employment Incentives to lower employment. During a time of crisis, it is intended to cover the costs of unemployment, where the Employment Incentives program, in addition to PLMP, is one of the main financial sources for helping unemployed people.

In contrast to the other studies (Table 1), our research did not provide statistical evidence of the positive impact of ALMP on employment. Because of the different direction of the impact of the programs under consideration; in our study, the impact of ALMP as a whole was not detected. On the other hand, 
the analysis of Laporšek and Dolenc (2011) showed that expenditures on an active labour market policy are positively related to the labour market, thus affecting a reduction in unemployment and an increase in the Employment Rate.

However, in different time frames and for different countries, the impact of different programs was found to be different. In two studies, Estevão (2003) and Estevão (2007) showed that the Training Program had no statistically significant effect on employment. Just opposite to our findings in his study as the most effective measures was contended the Employment Incentives program. Nie and Struby (2011) studied the impact of ALMP programs on unemployment rate and found that Training programs, along with Job-Search Assistance, are efficient in reducing the unemployment rate. They reported no impact of Employment Incentives and a negative impact of Direct Job Creation. Similar evidence manifesting inefficiency of the Employment Incentives program is reported by Boone and van Ours (2004). The introduction of the doubt in the efficiency of Employment Incentives program could be understand as a step from the evidence given in before mentioned studies to the results of our study.

The difference in the results of our study in comparison to the previous ones is the negative impact of the Employment Incentives program on Employment Rate. As other studies over different time frames report quite similar results, but opposite to our study, it is highly plausible that the difference is the result of the emergence of the financial crisis.

\section{Conclusion}

The challenge of the research was to analyse the impact of the ALMP programs on the Employment Rate in the EU Member States during the financial crisis. The aim of the research was to determine whether the expenditures for the pursuance of the ALMP programs had a positive impact on the Employment Rate in the EU Member States. The panel data model included data for twenty EU Member states within the financial framework in the period 2007-2013.

The answer to the research question was provided using the fixed effect panel regression model with Employment Rate as the dependent variable. The model indicated that the Training program had a positive impact on the Employment Rate, which meant that it maintained its role amongst Labour Market Policy measures even in a time of crisis. Supported to a certain extent by weaker statistical evidence, we found a negative impact of Employment Incentives program on Employment rate. Thus, we came to the conclusion that in the period of financial crisis, the investments in the Employment Incentives program were conditioned by the situation on the labour market. 
To summarise, the results of our research help in understanding the increase of the ALMP programs and measures and awareness of the impact of ALMP on the level of work activity in the EU. The study therefore provides an insight into the achieved success of the implementation of the ALMP programs in respect of dedicated expenditures during the financial crisis, which is the basis for possible improvements in the further implementation of the ALMP. It also contributes to comparing the performance of the ALMP between various financial frameworks $(2004-2006,2007-2013,2014-2020)$ in the EU. 


\section{References}

Andersen, T. M., and Svarer, M (2012). Active labour market policies in a recession. IZA Journal of Labour Policy, 1(1), pp. 1-19.

Babcock, L., Congdon, W. J., Katz, L. F. and Mullainathan, S. (2012). Notes on behavioral economics and labour market policy. IZA Journal of Labour Policy, 1(2), pp. 1-14.

Bánociová, A. and Martinková, S. (2017). Active Labour Market Policies of Selected European Countries and Their Competitiveness. Journal of Competitiveness, 9(3), pp. 5-21.

Bilić, N. and Jukić, M. (2014). Nezaposlenost mladih - ekonomski, politički i socijalni problem s dalekosežnim posljedicama za cjelokupno društvo. Pravni Vjesnik, 30(2), pp. 485-505.

Blanchard, O. J., Jaumotte, F. and Loungani, P. (2014). Labour market policies and IMF advice in advanced economies during the Great Recession. IZA Journal of Labour Policy, 3(2), pp. 1-23.

Bonoli, G. (2010). The political economy of active labour market policy. Politics \& Society, 38(4), pp. 435-457.

Boone, J. and van Ours, J. C. (2004). Effective Active Labour Market Policies. IZA Discussion Paper No. 1335(10), pp. 2-38.

Bredgaard, T. (2015). Evaluating what works for whom in active labour market policies. European Journal of Social Security, 17(4), pp. 436-452.

Brown, A.J.G. and Koettl, J. (2015). Active Labour Market Programs: Employment Gain or Fiscal Drain? IZA Journal of Labour Economics, 4(12), pp. 1-36.

Caliendo, M., and Schmidl, R. (2016). Youth unemployment and active labour market policies in Europe. IZA Journal of Labour Policy, 5(1), pp. 1-30.

Card, D., Kluve, J. and Weber, A. (2009). Active Labour Market, Policy Evaluations: A Meta-Analysis. IZA Discussion Paper No. 4002(2), pp. 1-35.

Card, D., Kluve, J. and Weber, A. (2017). What works? A meta analysis of recent active labor market program evaluations. Journal of the European Economic Association, 0(0), pp. 1-38.

Cerar Godec, L. (2017). Aktivna politika zaposlovanja v EU in uspešnost njenih programov. Magistrsko delo. Ljubljana: Fakulteta za upravo, pp. 1-75.

Cinalli, M., Giugni, M. and Graziano, P. R. (2013). Introduction: The policies of unemployment protection in Europe. International journal of social welfare, 22(3), pp. 287-289.

Clasen, J. and Clegg, D. (2006). Beyond activation reforming European unemployment protection systems in post-industrial labour markets. European Societies, 8(4), pp. 527-553.

Escudero, V. (2018). Are active labour market policies effective in activating and integrating low-skilled individuals? An international comparison. IZA Journal of Labor Policy, 7(4), pp. 1-26.

Estevão, M. (2003). Do Active Labour Market Policies Increase Employment? IMF Working Paper, 3, pp. 1-30.

Estevão. M (2007). Labour Policies to Raise Employment. Palgrave Macmillan Journals on behalf of the International Monetary Fund, (IMF Staff Papers), 54(1), pp. 113-138.

European Union (2013). Labour market policy statistics; Methodology 2013. Luxembourg: Publications Office of the European Union. At <http:// 
ec.europa.eu/eurostat/documents/3859598/5935673/KS-GQ-13-002-EN. PDF>, accessed 6 December 2016.

European Union (2016). Active labour market policies. At <http://ec.europa.eu/ europe2020/pdf/themes/24_almp_and_employment_services.pdf> accessed 3. May 2016.

Eurostat (2013). Labour market policy statistics Methodology 2013. At <http:// ec.europa.eu/eurostat/documents/3859598/5935673/KS-GQ-13-002-EN. PDF>, accessed 10 April 2016.

Eurostat (2016). Labour market policy. At <http://ec.europa.eu/eurostat/web/ labour-market/labour-market-policy>, accessed 5 April 2016.

Grubb, D. and Puymoyen, A. (2008). Long time series for public expenditure on labour market programmes. OECD Social, Employment and Migration Working Papers No. 73, (73), pp. 1-117.

Gujarati, D. N. (2004). Basic Econometric, Fourth edition. The McGraw-Hill Companies. At <https://docs.google.com/file/ d/0B61KSjKBWIfscmdkSVF6VF9ONjA/edit>, accessed 12 March 2017.

Hoechle, D. (2007). Robust standard errors for panel regressions with crosssectional dependence. Stata Journal, 7(3), 281-312.

Jacović, A. (2010). Politika trga dela. At <http://www.stat.si/statweb/Common/ PrikaziDokument.ashx?ldDatoteke=8145>, accessed 27 May 2016.

Južnik Rotar, L. (2011). Effectiveness of the Public Work Program in Slovenia. Managing Global Transitions, 9(3), pp. 275-287.

Kluve, J. (2006). The Effectiveness of European Active Labour Market Policy. RWI Discussion Papers, No. 37, pp. 1-46.

Kluve, J. (2010). The effectiveness of European active labour market programs. Labour Economics, 17(6), pp. 904-918.

Kluve, J. et al. (2007). Active Labour Market Policies in Europe Performance and Perspectives. Berlin: Springer - Verlag.

Kopač, A. (2002). Pasivna politika zaposlovanja - sistemi socialne varnosti za primer brezposelnosti. In I. Svetlik, J. Glazer, A. Kajzer and M. Trbanc, eds., Politika zaposlovanja. Ljubljana: Fakulteta za družbene vede, pp. 144-171.

Kraatz, S. (2016). Politika zaposlovanja. At <http://www.europarl.europa.eu/ atyourservice/sl/displayFtu.html?ftuld=FTU_5.10.3.html>, accessed 20 May 2016.

Laporšek, S. and Dolenc, P. (2011). Do Flexicurity Policies Affect Labour Market Outcomes? An Analysis of EU Countries. Croatian Journal of Social Policy, 19(2), pp. 107-129.

Leschke, J. (2011). Transition from Unemployment to Work and the Role of Active Labour Market Policies during the Lisbon Strategy Period and the Economic Crisis. European Trade Union Institute, Brussels, 7(1), pp. 135-170.

Martin, J.P. (2014). Activation and Active Labour Market Policies in OECD Coutries: Stylized Facts and Evidence on their Effectiveness. IZA Journal of Labour Policy, 4(1), pp. 1-33.

Matković, T., Babić, Z. and Vuga, A. (2012). Evaluacija mjera aktivne politike zapošljavanja 2009. i 2010. godine u Republici Hrvatskoj. Revija za socijalnu politiku, 19(3), pp. 303-336.

Nie, J. and Struby, E. (2011). Would Active Labour Market Policies Help Combat High U.S. Unemployment?. Economic Review, Academic Journal, 96(3), pp. 35-69. 
OECD (2016). Employment rate. At <https://data.oecd.org/emp/employmentrate.htm>, accessed 25 January 2017.

OECD (2016a). Labour force participation rate (indicator). At <https://data.oecd. org/emp/labour-force-participation-rate.htm>, accessed 12 May 2016.

OECD (2016b). Economic Outlook No 100 - November 2016: Output gaps: deviations of actual GDP from potential GDP as \% of potential GDP. At <http://stats.oecd.org/Index.aspx?Queryld=51655>, accessed 25 January 2017.

OECD (2016c). Public spending on labour markets. At <https://data.oecd.org/ socialexp/public-spending-on-labour-markets.htm>, accessed 25 January 2017.

OECD (2016d). Strictness of employment protection - individual and collective dismissals (regular contracts). At <https://stats.oecd.org/Index. aspx?DataSetCode=EPL_OV> accessed 25 January 2017.

OECD (2016e). Tax wedge. At <https://data.oecd.org/tax/tax-wedge.htm>, 25 January 2017.

OECD (2016f). Trade Union Density. At <https://stats.oecd.org/Index. aspx?DataSetCode=UN_DEN\#>, accessed 4 April 2016.

Sahnoun, M. and Abdennadher, C. (2018). The assessment of active labor market policies: evidence from OECD countries. Faculty of Economics and Management, pp. 1-27.

Svetin, I. and Osvald, T. (2016). Aktivno in neaktivno prebivalstvo, Slovenija. At <http://www.stat.si/statweb/Common/PrikaziDokument. ashx?ldDatoteke=7788>, accessed 21 November 2016 .

Svetlik, I. and Batič, M. (2002). Aktivna politika zaposlovanja. In I. Svetlik, J. Glazer, A. Kajzer and M. Trbanc, eds., Politika zaposlovanja. Ljubljana: Fakulteta za družbene vede, pp. 174-198.

Triantafillou, P. (2008). Normalizing active employment policies in the European Union: The Danish case. Routledge Taylor \& Francis Group, 10(5), pp. 689710.

Van der Ende, M., Peters, M., Biesma, A., Dimitrova, D. and Schneider, H. (2012). Analysis of costs and benefits of active compared to passive measures. Ecorys, IZA, Final report. At <http://ec.europa.eu/social/ BlobServlet?docld=7601\&langld=en>, accessed 14 December 2016.

Verbeek, M. (2004). A Guide to Modern Econometrics. 2nd edition. England: John Wiley and Sons Ltd. At <https://thenigerianprofessionalaccountant.files. wordpress.com/2013/04/modern-econometrics.pdf>, accessed 12 March 2017.

Vodovnik, Z. and Tičar, L. (2016). Osnove delovnega in socialnega prava (The Bases of Labour and Social Law). Ljubljana: GV Založba. 